\title{
CONTROL OF HOUSING ADMINISTRATION
}

\author{
WALTER H. BLUCHER*
}

In any discussion of the housing problem it is necessary that we first determine just what we are going to discuss and that we define some of the terms to be used. Since the housing problem under consideration at the present time involves "lowcost housing" or housing for "low-wage earners," it is essential that we determine what we mean by these terms. It has been customary to divide the American public into three income groups, that which has an income not exceeding $\$ 1,200$ per year, the group having an income between $\$ 1,200$ and $\$ 2,000$, and the other having an income in excess of $\$ 2,0000^{1}$ It is the writer's opinion that the income group making up the lowest third (income not to exceed $\$ 1,200$ ) should again be divided into three groups. At the very bottom of the lowest third is the group which has insufficient income to permit the payment of any rent. This is the "welfare group" or the "public aid group"-a group which in recent years has greatly increased. A certain class of people in America, however, will always require some form of public aid. Obviously, the housing which we are designing today is not housing for that "lowest third of the lowest third."

The middle third of the lowest third makes up that part of the population which at the present time is paying a rental of three or four dollars per room per month. This is, admittedly, a rough figure, but a survey of many of our larger cities will find a considerable part of the population residing in the blighted or slum areas in this class.

The upper third of the lowest third is that group which at the present time is paying five to seven dollars per room per month. On the lower east side of New York the average is approximately five dollars and fifty cents. It is generally admitted that this is a limited group and is probably the upper class of our so-called "lowincome group." About the only form of housing possible according to present plans, even with the Government subsidy, is that which will provide for this last-named group. Without further subsidies the two lower groups can not be reached.

There is, in addition, another group, intermediate between the low-income and medium-income groups, which is expected to pay between seven and twelve dollars

\footnotetext{
* LL.B., City Planner and Secretary, Detroit City Plan Commission; Director, National Conference on City Planning; President, Michigan Planning Conference; Consultant, National PJanning Board.

${ }^{1}$ Wood, Recent Trends in American Housing (1932) 52.
} 
per room per month. These are the tenants who are to be provided with housing facilities by the so-called limited dividend housing corporations. It is generally agreed that many of the people in this groüpare now paying a lower rental, and how their incomes are to be stretched to meet the new rental requirements has not yet been determined. It is equally obvious that the social status of the people in the various groups heretofore mentioned may be different, that the nature of the administration, the educational facilities, the care of the properties required will differ in the different income groups. It is necessary, therefore, that we determine at the outset just what groups we propose to re-house so that we may consider the administration of those groups only. Nothing could be gained through a discussion of the theoretical administration of housing units which admittedly cannot be built at the present time.

Housing is being undertaken by two groups. Originally most of the projects were started by limited dividend housing corporations which, though private, were subject to some form of public control. Such control was required by the terms of the Emergency Relief and Construction Act of 1932 in authorizing the Reconstruction Finance Corporation to make loans for housing. The present tendency is distinctly toward public housing ${ }^{2}$ since limited dividend housing has failed to produce results and since in public housing the federal government will grant up to 30 per cent of the cost of labor and materials.

There is no experience in America which can help guide us in the proposed public housing projects now under consideration. There is, admittedly, a field of housing experience in Europe, but because of the historic differences of the people, because of the difference in land tenure, the difference of the attitudes of European peoples toward government, toward public officials, and with respect to the responsibilities of the tenants, it can hardly be said that the European experience will necessarily show us in America how to proceed. ${ }^{3}$ We have had some experience with limited dividend housing corporations, notably in New York, but in every case the people housed are of a higher economic level than those groups which we propose to re-house at the present time. Since the economic status to some extent determines the social status, it would hardly be fair to say that the people in the proposed new housing developments will be of the same class or kind, that they will recognize the same obligations, or can be handled in the same manner. The writer is definitely of the opinion that the class of people to be re-housed in the new housing

\footnotetext{
$\approx$ We must determine what we mean by public housing. I understand it to mean housing undertaken by a public body such as a municipality or a state, which may or may not be constructed by that public body but which, we may assume, at least will be administcred by such a public body. It is, of course, necessary to include among such public bodies the federal Public Works Emergency Housing Corporation (PWEHC) although its exact relationship to the various local or state public bodics with which it will deal has not yet been determined.

'The newspapers of February 13, 1934, carried the story that Karl Marx Hof in Vienna had been shelled and razed. If the administration does not happen to be of the same political faith as the tenants in the building the thing to do is to destroy the building. All problems of administration are thereby solved. Simple-isn't it?
} 
developments, if we stand by our intention of providing low-cost housing, will, generally speaking, be a different group than that to be found in the limited dividend housing projects.

Public housing projects in America will necessarily be administered by public officials. The present tendency is to have housing commissions or authorities which are made up of non-salaried officials. As honorary commissions or authorities, the "stigma" of public service need not necessarily apply. These bodies are, however, made up of public officials, and in the eyes of a great body of American citizens a public official is a politician, and a politician is per se dishonest. This is the attitude of many of our "enlightened" citizens. They are unable to understand that there are in the public service many honest men and women who are desirous of contributing their best efforts to the public good. To them, a public official is necessarily one who is not interested in the public good but is interested only in his own personal aggrandizement. Because of this attitude it is difficult to obtain the public confidence which is so important in a project of this kind. There is, of course, some foundation for the general public attitude in view of the conditions prevailing in many of our larger cities. Many prominent citizens who would say, rightly or wrongly, at the very outset, that an honest administration of a public housing project in some of our American cities is impossible. It is here that the European countries have an advantage. 4 One of the essentials in administering the housing project will be the convincing of the public that the administrative group is interested only in the social well-being of the tenants. It is important, therefore, that every housing authority set up to administer a housing project be made up of outstanding public citizens who have the confidence of the community. The housing group should, of course, be composed of people who understand the social aspects of the problem. ${ }^{5}$

The editor has raised this question. "Can adequate assurance be given that a board (non-salaried) so constituted would persist in careful supervision of housing projects after the first wave of creative enthusiasm has given way to the more prosaic work of the administration?" It can safely be said that if the board is made up of the proper personnel, that is of members who at the outset take an interest in the work, that interest will continue. There has been adequate experience throughout the country to warrant this statement. The work of the State Housing Board of New York is proof of the assertion. There are at the present time in the United States hundreds of non-salaried boards. Most of the planning commissions in the United States are in that class. So, too, are most of the boards of appeals on zoning. In many instances interest in the work has continued over a period of years, provided there was some work to do. There are, of course, many city planning boards throughout the country which show no such interest, but in almost every instance that interest was not present upon the creation of the board. They were never told

\footnotetext{
- Perhaps the last sentence should be deleted in view of what has recently occurred in Europe.

s The question whether there should be a statutory distribution of the personnel among various occupations is discussed infra, p. 247 .
} 
what work they might do or how they might proceed to do it. No program was ever laid out. There are enough successful examples, however, to warrant the broad statement made that continuous interest can be obtained.

The method of appointment of the board raises some interesting questions. Since the Maryland Authority is a state board, it follows that the board was appointed by the Governor. ${ }^{6}$ The same is true of the New Jersey Authority. ${ }^{7}$ In Ohio an elaborate method of appointment has been set up. ${ }^{8}$ One of the appointments is made by the Probate Court, one by the Common Pleas Court, one by the Board of County Commissioners, and two by the mayor of the most populous city in the territory included in the district. In Michigan, although City Housing Commissions are created, the legislature at the very last minute placed the appointing authority in the hands of the Governor. ${ }^{9}$ If this were the accepted method, a rather anomalous situation might be created. The city board is appointed to do a job in the municipality. Funds for its organization are supposed to be provided in the first instance by the municipality. Interest in the project is purely local. There seems to be little reason, therefore, why the appointment should rest in the hands of the Governor. ${ }^{10}$ It seems consistent to say that for purely local authorities the appointment of the board should rest within the hands of the Mayor. Some criticism will result from those who say that there is apt to be less local politics if the board is appointed by the Governor. There is very little difference, however, between local and state politics.

About the best we can do at the present time is to put a series of questions regarding administration, which can be answered only by experience.

Do we want municipal control or is some further control essential? Is it necessary that we have a state group to supervise the local projects in addition to the local authority, or should there be a citizens group to check the official group? The problem is further complicated by the undetermined status of the Federal Public Works Emergency Housing Corporation (PWEHC). It is assumed that this corporation will, at the outset, undertake the development of some of the projects and that these will later be turned over to local authorities. How far the PWEHC will want to go in maintaining control of the development is not known, but it is reasonable to expect, since federal funds are involved, that the federal government will wish to maintain direct control over the project during its "paying-off" lifetime and that it will want to be assured of proper control after the amortization period has passed. It seems to the writer that such control is desirable. The attitude of the local authority might be that, since no local funds are involved, it would be desirable to decrease rents below an amount sufficient to cover all amortization, maintenance, and interest

\footnotetext{
'Md. Laws I933, c. 32.

'N. J. Laws 1933 , c. 444 .

"Ohio Laws 1933, Ist Spec. Sess., H. B. I9.

Mich. Pub. Acts 1933, 2nd. Extra Sess., No. Ir.

${ }^{10}$ The Governor of the State of Michigan was quoted as saying "I have borne in mind the fact that the slum clearance problem is a city and not a state problem. I can see no reason why the legislature should have put the duty of naming the commission on me instead of the Mayor."
} 
costs. Even an "honest"11 group might reach this conclusion. On the other hand, the pressure for special privileges within the housing area probably will be great, and even an "honest" authority may give way to it. Again, the authority may not think it dishonest to grant favors to the local officials by placing particular tenants in the houses. Since the federal government has an investment in the property, it is reasonable that it should have adequate control to see that that investment is properly safeguarded.

This does not necessarily mean that Washington should control every detail of the operation of the development. Certainly it should not control the purchase of necessary janitorial supplies or the hiring of janitors to suggest an extreme division. The point at which federal control stops and local control starts may be a difficult point to determine. As is stated later, the nature of the development will be a controlling factor. If the PWEHC retains the architects, constructs the buildings, and later turns the project over to a local board, some of the problems of control will have been eliminated. Authority for the appointment of the staff of the local authority should rest in its hands, but the federal government should have the right to direct the removal of any of the key men if they are found to be unqualified or inefficient and as a result endanger the project. The Michigan bill, when first presented, contained a provision that, with the exception of the director and secretary, all other employees should be subject to civil service. That provision was removed before final passage. ${ }^{12}$

A great many complications can arise from conflicts of authority. Let us assume that the local housing authority is appointed and that, in addition, the PWEHC will undertake the work-already we have established a point of conflicting authority. Add to this some of the provisions of the Michigan act and we find further complications because that act provides, among other things, as follows: "All deeds, contracts, leases, or purchases entered into by the commission shall be in the name of the city or village and shall be approved by the governing body of said city or village."13 If the housing authority is not to be autonomous but is to be subject to the control of the local legislative body, in addition to a possible control by the state housing board and by the federal authorities, some difficulty may be experienced in getting any work done.

If the local group is at all satisfactory it must be given wide powers. If it is not satisfactory, presumably the project will not be turned over to it by the PWEHC. Assuming that the local group is satisfactory, the PWEHC must treat it as honest

\footnotetext{
"Here a definition of the term "honest" is required-a proper definition of the term will list as "dishonest" any group which grants any kind of special privilege.

12 It is the 'writer's opinion that there should be no civil service control over the appointment of architects, engineers, lawyers, and planning consultants, nor should there be a requirement that any of these submit bids for the work. Technical and professional men of this character should be chosen because of their ability and experience rather than because of the low estimate that they put on the value of their services. There is no more sense in taking bids on the services of an architect, an engineer, or a lawyer, than there is in taking bids for the services of a doctor.

"Supra note 9, \$II.
} 
and trustworthy. There is another reason why the local group must be given wide authority. If its members are to take an interest in the project, they must feel that they have some control over it. They are certain to lose interest the moment they find they are merely serving as minor administrative officials for the federal government.

We have heretofore discussed the relationship between the PWEHC and the local authority. We may not necessarily assume that such relationship will exist in every case. There is a possibility that federal control will be exercised by the Public Works Administration as such and not through the PWEHC. The nature of that control should therefore be considered.

The writer has had an opportunity to examine the contract and schedules between the Juniata Park Housing Corporation and the United States (124 printed pages). In this contract there is to be found the control which a reasonable and careful lender of money would insist upon to safeguard his investment. In addition, however, certain special measures of control are to be found. For instance, the Government reserves the right to refuse to make an advance of funds "If in the judgment of the Government the financial condition or business prospects of the Borrower shall have unfavorably changed, to a material degree, from its condition or prospects as at any time theretofore represented to the Government; . . ."

In Section 24 of the contract it is agreed "that the Government shall have the right and power to regulate and control the management, operation, maintenance, and rentals of the Project. . . ." The scope of such right is defined in Part Four of the mortgage, but it is further outlined in a supplemental Supervision and Option Agreement. ${ }^{14}$

\footnotetext{
1"The Supplemental Supervision and Option Agreement mentioned above cites the previous contract with the Government and goes into considerable detail with respect to Government regulation. Among other things, the following is required: "The Government shall have the right and power at all times to regulate, supervise and control the management, operation, maintenance and rentals of the Project in addition to, but not in derogation of, the power of any such public authority or body so to regulate, supervise and control as provided in Section I hereof. The Government may, without limitation of the right and power herein granted to it:

(a) Order any such repairs as it may deem necessary or reasonably advisable to preserve the health and safety of the occupants of the building and structures embraced in the Project.

(b) Order the Corporation to do such acts as may be necessary to comply with the provisions of applicable laws or requirements of any public authority. . . .

(c) At all reasonable times, examine the Corporation, all books and accounts kept by it, ...

(c) Prescribe uniform methods and forms of keeping accounts, ...

(f) Require the Corporation to filc with the Government an annual report. . . .

(g) Regulate or restrict the salaries, commissions, or other fees paid to officers, employees, or agents of the Corporation, and regulate or restrict all contracts for the management of the Project or any part thereof which the Corporation may at any time enter into; and, to insure proper and efficient operation of the Project, require that persons of sufficient number and ability be emplojed by the Corporation, and at any time require the Corporation to discharge any persons employed on the Project.

(b) Limit, restrict, and regulate the lease or sale of the Project or any part thercof (including the rental and terms of sale price, and all other points involved), for stores, garages or any other business purposes, or for any other purpose other than as shown in the plans of the Project approved by the Government.
} 
Provision is later made for the acceleration of the debt "If the Mortgagor shall fail to comply with the orders, regulations, or requirements of the Government relating to the regulation and control of the management and operation of the mortgaged property. ..."

We may assume that similar control will be exercised in other projects of a like nature.

\section{State Housing Boards}

In fifteen states ${ }^{15}$ there are boards which supervise private limited dividend housing corporations. The relationship between these boards and the limited dividend housing corporation has been fairly well established through the New York practice. A reference to the New York law ${ }^{16}$ will show that the State Housing Board has rather wide control over their activities. There need be no misunderstanding as to the administration of projects of this kind. ${ }^{17}$

The control heretofore exercised by state housing boards over the activities of limited dividend housing corporations has been very broad. This is particularly true of New York where we have had the longest and best experience relating to them. The theory of this control probably rests on the basis that the corporation is given certain powers and privileges beyond those delegated to other private corporations and that in exchange for these advantages it subjects itself to this control. The two principal advantages are tax exemption and the power of eminent domain. In New York tax exemption has been granted, and, although the right of eminent domain exists, it is believed that it has never been exercised by a limited dividend housing corporation.

In some of the more recent acts, tax exemption has been eliminated so that the only advantage to these corporations is the theoretical power of eminent domain. Whether this is sufficient compensation for the strict control exercised by the state housing board is very questionable. The lack of results in limited dividend housing

(i) Fix, and from time to time revise, the maximum rentals or the maximum average rentals per room, ...."

The Supplemental Agreement also provides that the Corporation shall use a standard form of apartment lease which shall be satisfactory in form and substance to the Government.

A most important provision in the Supplemental Agreement is the option by which the Government is empowered to purchase the Project. The corporation agrees not to sell the Project without first offering the same to the Government. Moreover, the option may be exercised upon default in any of the terms of the option agreement.

${ }^{25}$ Arkansas, California, Delaware, Florida, Illinois, Kansas, Kentucky, Massachusetts, New Jersey, New York, North Carolina, Ohio, South Carolina, Texas, Virginia.

${ }^{23}$ N. Y. Laws 1926, c. 823, N. Y. Cons. Lsws (Cahill, I930) p. 278x.

${ }^{17}$ One of the persons who has had extensive contact with the State Housing Board of New York was asked his opinion with regard to the outstanding features of the New York experience. It was his opinion that one of the most important provisions of the law was that which provides for the acceptance of a designee of the Board of Housing as a member of the Board of Directors of the Limited Dividend Housing Corporation. This same person felt that provision in the law, giving the Board the power to prescribe accounting methods, was the second most useful device. It is suggested that reference be made to the comprehensive studies of housing conditions prepared by the State Housing Board as well as the Annual Reports of that Board. 
may be partly attributed to the fact that, particularly under the more recent housing laws, private capital does not feel that enough is to be gained through limited dividend housing to warrant subjection to such extensive control. In view of the limited dividend and the very apparent risks to capital, many operators feel that the advantage of eminent domain is not balanced by the disadvantages of control over plans, building, operation, accounting, etc.

The relationship of such state boards, however, to local municipal housing authorities is more involved. In some instances there may be slight control by the state board over the activities of the local board. In some cases this control amounts to almost no control at all.

The recently enacted Municipal Authority Act of the State of New York contains the following paragraphs: ${ }^{18}$

"67. Powers and duties of board. The board [the State Housing Board] shall collect and distribute information relating to the administration of housing authorities and to the construction, maintenance and operation of projects. The board shall suggest and assist in the preparation of legislation relating to housing authorities and their functions. The board may, in its discretion, prescribe methods and forms for keeping accounts, records and books to be used by an authority. The board may require an authority to file periodical reports not oftener than quarterly covering its operations and activities in a form prescribed by the board and may, from time to time, require specific answers to questions upon which the board may desire information. For the purpose of gathering information to enable the formulation of suggestions for legislation, the board may require an authority to submit additional information relating to the condition and affairs of an authority, its dealings, transactions or relationships.

"68. Projects. An authority shall file with the board a copy of each proposed project embodying the plans, layout, estimated costs and proposed method of financing. The board shall with reasonable promptness transmit to the authority its criticisms and suggestions. Any change made in the project shall be filed with the board by the authority. At any time, upon request of the authority, the board shall submit to the authority its criticisms and suggestions with reference to any change in the project."

It will be noted that the authority of the State Housing Board in New York is very limited. As a matter of fact, beyond the power to supervise accounts and obtain reports and information, there is hardly any authority other than that of suggestion and criticism. If the local project is not satisfactory to the State Board, there is apparently nothing that the Board can do about it.

Most of the state housing boards were created in order that they might meet the requirements of the Emergency Relief and Construction Act of $193^{2}$ and with the definite purpose of providing the necessary supervision and regulation for private limited dividend corporations. At the time of their creation there was little thought of municipal or public housing, and as a result the acts provide for very limited state control over municipal housing. In view of the present tendency toward public

${ }^{23} \mathrm{~N}$. Y. Laws 1934, c. 4 . 
housing, it is doubtful if much limited dividend housing will be undertaken. ${ }^{18 *}$ In that case, the present state housing boards will have little to do and as a result may, for all practical purposes, cease to function in most states. It appears, therefore, that if there is to be any state control over public housing it must be provided in the acts creating public housing bodies. The Ohio law ${ }^{19}$ affords an example.

Under the terms of that law the State Board of Housing has the following authority: (I) It has the power to determine the need for a local authority. ${ }^{20}$ (2) It determines and fixes the limits of the district to be included within the territory covered by the local authority. ${ }^{21}$ (3) It has the power to enlarge such territory. ${ }^{22}$ (4) The local housing authority has the right to eminent domain only with the approval of the State Board. ${ }^{23}$ (5) A report on "all accounting and other transactions" is to be transmitted to the State Board. ${ }^{24}$ (It would be very difficult at the present moment to determine what is meant by "other transactions.") (6) The local authority must present an annual report to the State Board. ${ }^{25}$ (7) The State Board has the power to determine whether the local authority may dissolve. ${ }^{28}$

Nothing is said to the effect that if plans are not satisfactory to the State Board they may be disapproved. The Board has considerable original authority since it may refuse to grant permission for the creation of the local authority and may also refuse to grant the power of eminent domain. These are rather effective powers. Having created the authority, however, and having granted the power of eminent domain, it will have very little control up to the time of dissolution.

The New Jersey law ${ }^{27}$ creates a state housing authority only. There can be no conflict unless local authorities are later created.

\section{Relation to Local Bodies}

An important question arises with respect to the relationship of a local housing authority to other city departments. In some cases the original plans have been de-

${ }^{23 s}$ But cf. p. 249, infra.

'Ohio Laws, r933, ist Spec. Sess., H. B. 19.

20 "Section 2. . . Whenever the state board of housing shall have determined that there is need for a housing authority in any portion of a county which comprises two or more political subdivisions but less than all the territory within the county, a metropolitan housing authority shall be created and the territorial limits thereof defined by said state board of housing. . . . After such Distriet has becn formed the state board of housing shall have power to enlarge the territory, within such District so as to include other political subdivisions. ..."

1 Ibid.

Ibid.

$2 t$ "Section 7. The housing authority shall have the power to eminent domain which shall be exercised only with the approval of the state board of housing. . . ."

24 "Section 8. . . . and all accounting and other transactions of the authority shall be subject to the inspection and approval of the bureau of inspection and supervision of public offices of the state of Ohio, which shall transmit its report to the state board of housing."

25 "Section ro. Said authority shall keep an accurate account of all its activities and of all reccipts and expenditures and make an annual report thereof to the state board of housing. . . ."

$x^{\circ}$ "Section 12. Whenever the housing authority desires to discontinue its operations it shall make application to the state board of housing, for authority to dissolve. If such application be granted, the state board of housing shall take possession and dispose of all property, belonging to the housing authority, ..."

${ }^{\pi}$ N. J. Laws 1933, c. 444. 
veloped by the local city plan commission. That commission presumably has made a study of the entire city and is in the best position to determine in what areas new housing facilities are required. Shall the city plan commission or the housing authority have the final word as to what areas should be developed? Shall the housing authority be a designing authority, or shall the city plan commission have a veto power with respect to the general layout of the development?

The relationship of the local authority to the local legislative body is also important. In many cases streets and alleys will have to be vacated. Final authority for such vacations rests in the local legislative body, and the housing project can be effectively blocked if the necessary coopperation is not given by the legislative body in the way of street re-planning. Here again the city plan commission enters into the picture.

Assuming that the housing authority is to call upon other municipal departments for aid, how are the costs of those services to be determined? Shall the housing authority be charged for engineering services, or are those charges to be considered a part of the general cost of maintaining the community? How far is the municipality expected to go in providing municipal services without charge? What about relocation of sewers, water mains, lighting poles, hydrants? What about park and playground maintenance? The Michigan $\mathrm{Act}^{28}$ provides that the housing commission shall have the power-

"(c) To control and supervise all parks and playgrounds forming a part of such housing development but may contract with existing departments of the city or village for operation or maintenance of either or both."

"( $f)$ To call upon other departments for assistance in the performance of its duties, but said departments shall be reimbursed for any added expense incurred therefor."

It begins to be apparent that unless there is a high degree of coöperation between the housing authority and other municipal departments, there will be many "obstructions in the road" leading toward perfect administration.

\section{Personnel of Board}

Shall the housing authority, when set up, represent various professions? Shall the law provide that one must be a social worker, another a sociologist, another an architect, a lawyer, a business man, a realtor, a builder, an engineer? In none of the acts cited in this article is provision made for classification by occupation. This is rather surprising in view of the strong sentiment (not necessarily based upon experience) to be found in many parts of the country for such a classification. The writer is of the opinion that classifications of this kind are not essential, that the particular profession is not important because there are poor men to be found in every profession. It is most essential that the commission be made up of highminded, socially-minded, and honest persons. A social worker would be desirable-

"St. pra note 9, Sec. 7 (c). 
so would a sociologist-so would all of the others, but occupation alone will not insure intelligent and sympathetic administration. ${ }^{29}$

The powers and duties of the administrative authority are important in this connection. If the commission is to acquire the land, supervise the preparation of plans, contract for and supervise construction, one type of commission might be needed. On the other hand, if the commission is to take over a completed project and merely administer it, still another type of commission might do a better job. If the commission is to be merely an operating commission, many of the questions raised with respect to conflict with other city departments may never arise.

It is difficult to discuss control of administration without going into the realm of actual administration of the unit. Many problems, of course, will arise there. In the case of a negro development, shall there be negro representation on the authority? Shall the director of the project be a negro? Shall the rent collectors, police, school teachers, etc., etc., be negroes? All of these problems enter into the proper administration and are therefore relevant to its control.

One other point should be considered. Little attention has been given to the status of housing or of housing boards after the federal funds have been exhausted. What organizations may be created when housing as a federal function ends?

One thing is certain: the property owners in the affected areas will be forced to merge their interests in some way if any housing is to be done. It is elementary that re-housing on individual sites can not be done and that we must have large-scale or community projects. It is also obvious that in the financing of rehabilitation projects we can not anticipate the purchase of the land or large loans to cover the land cost. Property owners in blighted areas must assume part of the burden.

In the city of Detroit this was the first method attempted for re-housing. A corporation known as the Rehabilitation Association was organized for the purpose of merging the interests of the property owners in re-planned areas. It was proposed

$\Rightarrow$ The Housing Authority of the City of Toledo, according to the Architectural Forum, consists of Charles F. Weilcr, dry goods man; Leonard C. Price, secretary of the Toledo Real Estate Board; the Rev. Calvin K. Stalnaker; Miss Amy Maher, social worker; and C. J. Bushnell, University Professor.

The Detroit Housing Commission consists of a physician, the president of a civic study club, a real estate man, a radio announcer, and a business man.

The Cleveland authority consists of the president of the Jewish Socal Service Bureau, the president of the Catholic Charities Corporation, the president of the Cleveland Welfare Federation, the editor of the Cleveland Citizen (which is the official organ of the Cleveland Federation of Labor), and a retired contractor.

The Cincinnati authority consists of a former president of the Better Housing League, chairman; the other menbers are a lawyer (former county prosecutor and member of the Board of County Commissioners for scveral years), the dircetor of the work of the Forcign Policy Association, a rcal estate man, and a former executive of Proctor \& Gamble Company.

The New Jersey State Board consists of Dr. Edith Elmer Wood (see p. 137, supra), the comptroller of the Port of New York, a vice-president of the Western Electric Company, and one of the civic leaders in women's organizations.

(Information as to the Cleveland, Cincinnati, and New Jerscy bodies was obtained from the National Association of Housing Officials). 
that the owners exchange the titles to their properties for corporate stock. It would have been possible for the corporation to borrow the necessary funds for the buildings, and it was anticipated that a limited dividend would be paid on the corporate stock. This plan was proceeding in a fairly successful manner when public housing came to the fore in Detroit with the result that this form of project was dropped. An outstanding difficulty of course in the creation of such organizations is the acquisition of all of the property. A means must be provided for the acquisition of property which is "held out." Under the provisions of limited dividend housing laws the power of eminent domain might be delegated to such a coöperative organization after it has obtained 75 per cent of the property. In all probability payment in cash would have to be made for this property, which of course raises another question. In the Detroit project it was proposed that the value of the land for stock purposes be established at the 1933 assessed value of the land and buildings (which is about 45 per cent of the 1927 assessed value), in which case all of the property owners would merge their interests on an equal basis.

It is believed that the underlying principle for this form of set-up is sound and that in the future housing will have to be done somewhat on this basis. Where property has no value today, a plan providing for a reasonable and limited dividend on the land without any of the worries of taxation, collections, rent delinquency, etc., may induce a number of the owners to merge their property interests to carry it out. Such organizations will, of course, require some public supervision. Perhaps the experience in the control of existing limited dividend corporations will serve as a guide in determining how far it should extend.

In summing up, the first essential, and the most important essential of any administration, is that the authority be made up of honest, sympathetic, and socially-minded citizens. It must be admitted at the very outset that we are travelling upon very thin ice in our proposed housing projects. Although we are attempting to provide housing for the "low-income" group it is possible at the present time to provide new housing facilities for only part of that group. With our lack of experience it will be very easy to destroy any housing project. The causes for such destruction are many. The lack of sympathetic and honest administration can very definitely ruin any project because there will be many influences helping to cause such destruction by those who are not in sympathy with the movement. Any housing project must therefore have more than ordinary attention. These projects are "marginal" in nature. They have a chance to succeed only if all elements work in favor of the project. The second essential is that there be active coöperation between the authority and all other local, stgte, and federal agencies. There are, of course, other important essentials, but these two stand out. With an honest and sympathetic administration, interested only in the proper control and development of the housing project, there is some chance of success. Without it, it is very easy to forecast failure. 